ALCHEMY Jurnal Penelitian Kimia

Laman resmi: https://jurnal.uns.ac.id/alchemy

\title{
Pengukuran Total Fenolik, Flavonoid, Aktivitas Antioksidan dan Antidiabetes Ekstrak Etil Asetat Daun Katemas (Euphorbia heterophylla, L.) Secara In Vitro dan In Silico Melalui Inhibisi Enzim $\alpha$-Glukosidase
}

\author{
Rahmiwati Hilma*, Netti Gustina, Jufrizal Syahri \\ Program Studi Kimia, Universitas Muhammadiyah Riau, Jl. Tuanku Tambusai Ujung No 2, Pekanbaru 28294, Telp/Fax: (0761) 839577 \\ "Corresponding author: rahmiwatihilma@umri.ac.id \\ DOI: 10.20961/alchemy.16.2.40087.240-249
}

Received 19 February 2020, Accepted 02 September 2020, Published 18 September 2020

Kata kunci:
Euphorbia
heterophylla L.;
DPPH;
$\alpha$-glukosidase;
in silico;
in vitro.

Keywords:

Euphorbia heterophylla L.; DPPH; $\alpha$-glukosidase; in silico; in vitro.

\begin{abstract}
ABSTRAK. Tujuan dari penelitian ini adalah untuk mengetahui aktivitas antioksidan dan antidiabetes ekstrak etil asetat daun katemas (Euphorbia heterophylla L.) secara in vitro dan in silico melalui inhibisi terhadap enzim $\alpha$-glukosidase. Pada penelitian ini ekstraksi sampel dilakukan menggunakan maserasi bertingkat, dimulai dengan n-heksana, selanjutnya dengan etil asetat. Ekstrak etil asetat yang didapatkan dilakukan pengujian kuantitiatif total fenolik dan flavonoid. Uji aktivitas antioksidan terhadap ekstrak dilakukan menggunakan metode DPPH. Uji aktivitas antidiabetes terhadap ekstrak dilakukan secara in vitro dan in silico melalui inhibisi terhadap enzim $\alpha$-glukosidase menggunakan akarbose sebagai standar. Uji aktivitas antidiabetes terhadap kandungan senyawa bioaktif ekstrak secara in silico atau molecular docking menggunakan software Discovery Studio 4.1. Hasil penelitian menunjukkan bahwa nilai total fenolik dari ekstrak adalah 4,24 mg GAE/g berat kering dan nilai flavonoid total adalah: 3,22 mg KE/g berat kering. Hasil uji aktivitas antioksidan ekstrak didapatkan nilai IC 50 sebesar 37,56 $\mu \mathrm{g} / \mathrm{mL}$, digolongkan sebagai aktivitas antioksidan yang sangat kuat. Hasil uji aktivitas antidiabetes secara in vitro didapatkan nilai $I C_{50}$ sebesar 138,63 $\mu \mathrm{g} / \mathrm{mL}$. Hasil molecular docking memperlihatkan bahwa senyawasenyawa aktif yang terdapat didalam ekstrak mampu membentuk ikatan hidrogen antara ligan dengan reseptor, tapi lebih sedikit jika dibandingkan dengan akarbose.
\end{abstract}

\begin{abstract}
Measurement of Total Phenolic, Flavonoids, Antioxidant and Antidiabetic Activity of Catemas Leaf Ethyl Acetate Extract (Euphorbia heterophylla L.) by In Vitro and In Silico through Enzim $\boldsymbol{\alpha}$-Glucosidase Inhibition. This study aims to determine the antidiabetic activity of katemas (Euphorbia heterophylla L.) ethyl acetate extract in vitro and in silico through inhibition of the $\alpha$ glucosidase enzyme. In this study, the sample extraction was carried out by multilevel maceration, starting with n-hexane, then with ethyl acetate. The ethyl acetate extract obtained was quantitatively tested by total phenolic and flavonoids. The antioxidant activity of the extract was tested using the DPPH method. The antidiabetic activity of the extract was examined through inhibiting the enzyme $\alpha$ glucosidase in vitro using a microplate reader and in silico (molecular docking) using Discovery Studio 4.1 software. The results showed that the total phenolic value of the extract was $4.24 \mathrm{mg}$ GAE/g of dry weight, and the total flavonoid value was $3.22 \mathrm{mg} \mathrm{KE} / \mathrm{g}$ of dry weight. Antioxidant activity test obtained $\mathrm{IC}_{50}$ of $37,56 \mu \mathrm{g} / \mathrm{mL}$, classified as very strong antioxidant. The in vitro antidiabetic test examined that $\mathrm{IC}_{50}$ is $138.63 \mu \mathrm{g} / \mathrm{mL}$. The results of molecular docking showed that the active compounds in the extracts are able to form hydrogen bonds between ligand and receptor; however, the amount was less than the hydrogen bonds formed by acarbose.
\end{abstract}

\section{PENDAHULUAN}

Diabetes mellitus (DM) adalah penyakit kelainan metabolisme yang ditandai oleh hiperglikemia atau peningkatan kadar glukosa darah serta dan gangguan atau perubahan pada metabolisme karbohidrat, protein dan lemak sebagai hasil dari sekresi atau aktivitas insulin yang abnormal (Obafemi, 2017; Pichaya, 2016; Archana, 2011). Menurut data International Diabetes Federation (IDF) tahun 2013 melaporkan bahwa \pm 382 juta penduduk dunia menderita DM, diperkirakan akan mencapai 592 juta jiwa pada tahun 2035. Berat badan yang berlebihan dan kurangnya aktivitas fisik menjadi penyebab utama dari DM tipe-2 tersebut (Olokoba et al., 2012 dan Sui et al., 2016).

International Diabetes Federation (IDF) tahun 2013 menyatakan bahwa revalensi diabetes melitus di Indonesia sekitar 4,8\%. IDF juga menyatakan bahwa sekitar 382 juta penduduk dunia menderita diabetes melitus pada tahun 2013 diperkirakan prevalensinya akan terus meningkat dan mencapai 592 juta jiwa pada tahun 2035. Dalam penanggulangan penyakit diabetes, obat-obatan antidiabetes hanya merupakan pelengkap dari diet. Obat- 
obatan tersebut hanya perlu diberikan bila pengaturan diet secara maksimal tidak mampu mengendalikan kadar gula darah. Penggunaan obat-obatan sintesis antidiabetes harus benar-benar dipahami, agar ada kesesuaian antara dosis dengan indikasinya, tanpa menimbulkan efek samping yang tidak diinginkan (Dalimartha and Adrian, 2012). Penghambatan enzim $\alpha$-glukosidase dapat membatasi kadar glukosa darah dengan memperlambat atau menunda proses hidrolisis dan absorbsi karbohidrat. Akarbose merupakan suatu oligosakarida yang secara reversibel dapat menghambat enzim $\alpha$-glukosidase sehingga pemecahan karbohidrat kompleks dan disakarida menjadi monosakarida terhambat. Penggunaan akarbose dalam jangka panjang dapat memberikan efek samping pada saluran pencernaan seperti perut kembung (flatulence), diare, distensi abdomen, dan keroncongan (borborygmus) (Walker et al., 2012). Adanya efek samping yang tidak diinginkan inilah yang mendasari munculnya berbagai penelitian dalam upaya mencari alternatif terapi DM tipe 2, khususnya melalui mekanisme penghambatan enzim $\alpha$-glukosidase. Pemberian senyawa antioksidan sintetik maupun alami disamping obat diabet pada penderita DM diyakini bisa membantu penderita DM dalam mempercepat penyembuhannya. (Widowati, 2008). Tumbuhan mempunyai potensi sebagai sumber antioksidan yang memiliki efek menguntungkan untuk pencegahan diabetes dan penyakit kronis lainnya. Antioksidan alami berperan untuk merangsang kerja antioksidan endogen menetralkan stres oksidatif. Senyawa metabolit sekunder seperti: fenolik, flavonoid, terpenoid, alkaloid pada tanaman dengan karakteristik gugus fungsi spesifik yang terikat padanya berperan pada aktivitas antioksidan tanaman tersebut (Paul et al., 2013).

Pengobatan tradisional biasanya memanfaatkan tanaman berkhasiat obat. Pengobatan tradisional dengan tanaman obat menjadi langkah alternatif untuk mengatasi DM. Indonesia memiliki kekayaan hayati yang sangat besar. Berbagai jenis tumbuhan di negeri ini telah menjadi sumber potensial untuk agent erapeutik selama bertahun-tahun dan telah banyak yang berkembang menjadi obat-obatan modern (Febrinda, 2013). Masyarakat di Indonesia sudah biasa menggunakan obat-obatan tradisional yang berasal dari tumbuh-tumbuhan untuk mencegah atau mengobati penyakit. Salah satu tanaman yang dijadikan obat-obatan tradisional adalah daun katemas (Euphorbia heterophylla L.). Daun katemas banyak digunakan oleh masyarakat di daerah Ternate, Maluku Utara. Masyarakat menggunakan tanaman ini sebagai obat untuk mengatasi kesulitan buang air besar. Studi pendahuluan mengenai fitokimia daun katemas (E. heterophylla L.) yang diekstrak dengan n-heksana, etil asetat dan etanol menunjukkan adanya senyawa aktif flavonoid, saponin, alkoloid, tanin, diterpen dan ester (Falodun et al., 2006; James et al., 2010 dan Hilma et al., 2017).

Beberapa penelitian sebelumnya menunjukkan estrak etanol dan air menunjukkan aktivitas penyembuhan luka yang signifikan ketika ekstrak diberikan pada tikus (James et al., 2010). Falodun et al., (2006) menemukan bahwa estrak daun katemas (E. heterophylla L.) juga dapat digunakan sebagai anti inflamasi. Secara tradisional daun katemas (E. heterophylla L.) digunakan untuk mengobati sembelit, bronkitis, dan asma (Falodun et al., 2006). Hilma et al. (2017) mengatakan bahwa ekstrak daun katemas memiliki aktivitas antioksidan terhadap penangkapan radikal bebas DPPH. Beberapa tanaman famili Euphorbia dilaporkan mempunyai aktivitas antidiabetes, diantaranya: E. hirta (Kumar et al., 2010), E. neriifolia L. (Mansuri et al., 2012) dan ekstrak air E. heterophylla L. juga pernah dilaporkan mempunyai aktivitas (Annapurna et al., 2014). Dari literatur tersebut kemungkinan besar ekstrak etil asetat E. heterophylla L. dapat juga berpotensi sebagai antidiabetes.

Tujuan dari penelitian ini adalah untuk mengetahui kandungan total fenolik, flavonoid, aktivitas antioksidan dan antidiabetes ekstrak etil asetat daun katemas (Euphorbia heterophylla L.) secara in vitro dan in silico (molecular docking) melalui inhibisi terhadap enzim $\alpha$-glukosidase. Molecular docking dilakukan untuk mengkonfirmasi ikatan hidrogen dan energi ikatan senyawa bioaktif didalam ekstrak dengan asam amino dari protein enzim $\alpha$-glukosidase.

\section{METODOLOGI PENELITIAN}

Alat-alat yang digunakan dalam penelitian ini adalah, neraca analitik (Shimadzu), rotary evaporator (Buchr), seperangkat alat destilasi, mikropipet $10-100 \mu \mathrm{L}$ (merck), oven (Memmert), microplate reader, lampu UV dengan $\lambda=254 / 366 \mathrm{~nm}$ (Camag®), dan alat-alat gelas yang biasa digunakan di Laboratorium. Perangkat keras komputer, perangkat lunak yang digunakan untuk persiapan ligan, untuk molecular docking, untuk preparasi dan visualisasi ligan, adalah Discovery Studio 2016 (Kerjasama UMRI dan Universitas Kebangsaan Malaysia).

Bahan yang digunakan dalam penelitian ini adalah daun katemas (Euphorbia heterophylla L.), $n$-heksana destilasi (Brataco), etil asetat destilasi (Merck), etanol p.a (merck), methanol destilasi (Merck), aquades, DPPH (Sigma-Aldrich), $\alpha$-Glukosidase dari Saccharomyces cerevisiae (EC 3.2.1.20), p-nitrophenyl- $\alpha$-D- 
glucopyranoside (pNPG) (Sigma-Aldrich), akarbose (Sigma-Aldrich), buffer potassium fosfat (pH 7), dimethylsulfoxida (DMSO) p.a (Merck), larutan $\mathrm{Na}_{2} \mathrm{CO}_{3}$ (Merck), asam Gallat (Santa Cruz), Folin-Ciocalteu (Sigma-Aldrich), kuarsetin (Santa Cruz), $\mathrm{NaNO}_{2}$ (Sigma-Aldrich), $\mathrm{AlCl}_{3} .6 \mathrm{H}_{2} \mathrm{O}$ (Sigma-Aldrich), $\mathrm{NaOH}$ (Merck), Senyawa murni untuk moleculer docking adalah hasil isolasi oleh peneliti sebelumnya: cardiac glycosides (1) oleh Jalyeslml et al., 2010, ricinine (2) oleh Rumape et al., 2013, tanin prosianidin (3) oleh Yang et al., 2009, stigmast-4-ene-3-one (4) oleh Barla et al., 2006.

\section{Prosedur Penelitian}

Daun katemas diambil di Jalan Kartama Pekanbaru Riau sebanyak \pm 6000 g. Daun katemas dibersihkan, setelah itu dikering anginkan sampai beratnya konstan, setelah kering daun katemas dipotong kecil-kecil, dirajang dan dihaluskan hingga diperoleh serbuk kering yang disebut simplisia sebanyak $3000 \mathrm{~g}$.

Simplisia daun katemas dimaserasi menggunakan pelarut dalam botol gelap dengan perbandingan massa simplisia dengan volume pelarut adalah $1: 10$ (BPOM, 2008). Pelarut yang digunakan untuk maserasi awal adalah pelarut $n$-heksana. Simplisia dimaserasi selama 3 hari tanpa penggantian pelarut, dan terlindung dari cahaya matahari. Kemudian maserat disaring menggunakan kertas saring kemudian dipekatkan menggunakan alat rotary evaporator hingga didapatkan ekstrak kental $n$-heksana. Setelah dimaserasi dengan $n$-heksana, selanjutnya residu dimaserasi kembali dengan pelarut etil asetat sebanyak 3 x 24 jam. Kemudian maserat dipekatkan menggunakan alat rotary evaporator sehingga diperoleh ekstrak etil asetat daun katemas.

Larutan induk asam galat $1000 \mathrm{ppm}$ dibuat dengan menimbang $2 \mathrm{mg}$ asam galat yang kemudian dimasukkan ke dalam $2 \mathrm{~mL}$ labu takar. Dari larutan induk yang telah dibuat tersebut, dibuat deret standar dengan konsentrasi 20, 40, 60, 80 dan $100 \mu \mathrm{g} / \mathrm{mL}$. Kemudian ditambahkan $10 \mu \mathrm{L}$ reagen Folin-Ciocalteu 0,25 N didiamkan selama 5 menit kemudian ditambahkan $20 \mu \mathrm{L} \mathrm{Na}_{2} \mathrm{CO}_{3} 7,5 \%$ hingga terjadi perubahan warna menjadi biru, diinkubasi selama 30 menit. Serapan larutan dengan variasi konsentrasi tersebut dibaca menggunakan spektrofotometer UV dengan panjang gelombang serapan maksimun $765 \mathrm{~nm}$. Data absorbansi yang diperoleh kemudian digunakan untuk menentukan persamaan regresi larutan standar.

Sebanyak $100 \mu \mathrm{L}$ sampel, asam galat atau blanko dicampur dengan $10 \mu \mathrm{L}$ reagen Folin-Ciocalteu $0,25 \mathrm{~N}$, didiamkan selama 15 menit. Setelah itu, sebanyak $20 \mu \mathrm{L} \mathrm{Na}{ }_{2} \mathrm{CO}_{3} 7,5 \%$ ditambahkan ke dalam setiap sumur (well), terjadi perubahan warna menjadi biru. Campuran diinkubasi selama 30 menit di tempat gelap sebelum absorbansi diukur pada panjang gelombang $765 \mathrm{~nm}$. Kadar fenolik dihitung dengan memasukkan hasil serapan kadar ke dalam kurva baku yang telah dibuat.

Dibuat larutan induk kuarsetin 1000 ppm. Ditimbang 2 mg kuarsetin, dimasukkan kedalam $2 \mathrm{ml} \mathrm{labu} \mathrm{takar.}$ Dari larutan induk yang telah dibuat tersebut, dibuat deret standar dengan konsentrasi 20, 40, 60, 80, dan $100 \mu \mathrm{g} / \mathrm{mL}$. Kemudian ditambahkan dengan $60 \mu \mathrm{L} \mathrm{NaNO}{ }_{2} \%$, diamkan selama 5 menit, ditambahkan $50 \mu \mathrm{L}$ $\mathrm{AlCl}_{3} .6 \mathrm{H}_{2} \mathrm{O} 10 \%$, terjadi perubahan warna menjadi kuning, diamkan selama 30 menit dan terakhir ditambahkan $30 \mu \mathrm{L} \mathrm{NaOH} 1 \mathrm{M}$. Diinkubasi selama 5 menit. Larutan dengan variasi kadar tersebut dibaca serapannya pada microplate reader dengan panjang gelombang serapan maksimun $510 \mathrm{~nm}$. Kemudian dari absorbansi tersebut ditentukan persamaan regresinya.

Sebanyak $100 \mu \mathrm{L}$ sampel dicampurkan dengan $60 \mu \mathrm{L} \mathrm{NaNO}_{2}$ 5\% diamkan selama 5 menit, tambahkan $50 \mu \mathrm{L} \mathrm{AlCl} 3.6 \mathrm{H}_{2} \mathrm{O} 10 \%$ terjadi perubahan warna menjadi kuning, didiamkan selama 5 menit dan terakhir ditambahkan $30 \mu \mathrm{L} \mathrm{NaOH} 1 \mathrm{M}$. Kemudian campuran diinkubasi di tempat gelap pada suhu ruang selama 5 menit. Absorbansi campuran diukur pada panjang gelombang $510 \mathrm{~nm}$. Kadar flavonoid dihitung dengan memasukkan hasil serapan kadar kedalam kurva baku yang telah dibuat.

Sebanyak $100 \mu \mathrm{L}$ larutan ekstrak dengan konsentrasi $1000 \mu \mathrm{g} / \mathrm{mL}$ dimasukkan ke dalam sumur-sumur pada baris A. Sebanyak $50 \mu \mathrm{L}$ metanol dipipet ke dalam sumur-sumur pada baris B-H. Kemudian larutan ekstrak pada baris A dipipet sebanyak $50 \mu \mathrm{L}$ dengan pipet mikro multichannel dan dimasukkan ke dalam baris B, larutan pada baris B dipipet $50 \mu \mathrm{L}$ dan dimasukkan ke dalam baris C, dan seterusnya sampai baris F. Selanjutnya larutan pada baris F dipipet sebanyak $50 \mu \mathrm{L}$ dan dibuang, sehingga diperoleh larutan uji dengan konsentrasi $1000 \mu \mathrm{g} / \mathrm{mL}$ (baris A), $500 \mu \mathrm{g} / \mathrm{mL}$ (baris B), $250 \mu \mathrm{g} / \mathrm{mL}$ (baris C), $125 \mu \mathrm{g} / \mathrm{mL}$ (baris D), $62,5 \mu \mathrm{g} / \mathrm{mL}$ (baris E) dan $31,25 \mu \mathrm{g} / \mathrm{mL}$ (baris F). Baris A-G ditambahkan $80 \mu \mathrm{L}$ larutan DPPH $80 \mu \mathrm{g} / \mathrm{mL}$. Baris H hanya berisi metanol sebagai blanko. Larutan uji diinkubasi selama 30 menit pada temperatur ruang dengan membungkus 96 well microplate menggunakan alumunium foil. Setelah 30 menit, absorbansi larutan uji diukur pada panjang gelombang $517 \mathrm{~nm}$ dengan microplate reader.

Aktivitas penghambatan $\alpha$-glukosidase ditentukan sesuai modifikasi metode Rynjah et al., 2018, menggunakan mikroplate (ELISA reader). Campuran pereaksi yang digunakan dalam uji ini mengandung $50 \mu \mathrm{L}$ 


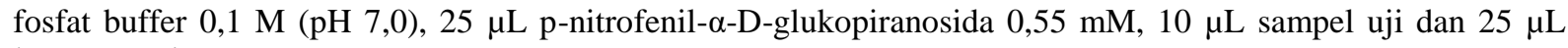
larutan enzim $\alpha$-glukosidase $(1 \mathrm{mg} / \mathrm{mL})$. Campuran reaksi kemudian diinkubasi pada suhu $37{ }^{\circ} \mathrm{C}$ selama 30 menit. Reaksi dihentikan dengan penambahan $100 \mu \mathrm{L} \mathrm{Na}_{2} \mathrm{CO}_{3} \quad 0,2 \mathrm{M}$. Hidrolisis enzimatik substrat dimonitor oleh jumlah $p$-nitropenol yang dilepaskan didalam campuran reaksi pada $\lambda 410 \mathrm{~nm}$. Kontrol positif yang digunakan ialah akarbose. Blanko digunakan untuk mengkoreksi absorbansi. Blanko adalah larutan uji yang terdiri dari sediaan enzim tanpa ekstrak. Pengujian dilakukan tiga kali ulangan. Aktivitas penghambatan (\%) dihitung dengan menggunakan persamaan berikut :

$$
\% \text { Inhibition }=\frac{A c-A s}{A c} \times 100
$$

Keterangan: $\mathrm{Ac}=$ nilai absorbansi kontrol dan As = nilai absorbansi sampel .

Nilai persen inhibisi yang telah dihitung dari setiap konsentrasi selanjutnya digunakan untuk perhitungan $\mathrm{IC}_{50} . \mathrm{IC}_{50}$ atau Inhibitor Concentration 50\% adalah nilai konsentrasi suatu bahan untuk menghambat aktivitas enzim $\alpha$-glukosidase sebesar 50\%. Nilai konsentrasi dari larutan yang telah diencerkan dari sampel dan persen inhibisi diplotkan pada sumbu $\mathrm{x}$ dan $\mathrm{y}$, kemudian nilai $\mathrm{IC}_{50}$ dihitung dengan regresi linear:

$$
\mathrm{y}=\mathrm{a} \ln (\mathrm{x})+\mathrm{b}
$$

Keterangan: $\mathrm{y}=\%$ Inhibisi, $\mathrm{X}=$ konsentrasi sampel, $\mathrm{A}=$ intersep, dan $\mathrm{B}=$ slope.

\section{Docking Molekul}

Discovery studio ${ }^{\circledR} 4.1$ dan UCSF CHIMERA digunakan untuk melakukan docking molekuler empat senyawa yang pernah diisolasi dan dilaporkan dari tanaman famili Euphorbia. Senyawa-senyawa ini digunakan untuk memprediksi aktivitas antidiabetes tanaman E. heterophylla L. secara molecular docking, karena diyakini senyawa-senyawa ini juga terdapat didalam tanaman E. heterophylla L., yaitu senyawa cardiac glycosides (1) (Jalyeslml et al., 2010). Senyawa ricinine (2) merupakan golongan alkaloid (Rumape et al., 2013). Senyawa tanin prosianidin (3) (Yang et al., 2009). Senyawa stigmast-4-ene-3-one (4) merupakan turunan dari saponin triterpen (Barla et al., 2006).

Struktur protein 3 dimensi diambil dari situs bank protein (www.pdb.org) dengan kode akses 3 W37 yaitu protein $\alpha$-glukosidase dengan ligan akarbose. Molekul protein dipreparasi dengan menghilangkan gugus $\mathrm{H}_{2} \mathrm{O}$ (jika ada), Pemisahan ligan alami yang terdapat pada molekul protein dan menambahkan atom hidrogen dan menentukan sisi aktif dari protein. Senyawa usulan yang akan dilakukan proses docking disebut sebagai ligan. Ligan juga harus dilakukan persiapan sebelum dilakukan proses docking untuk mendapatkan konformasi ligan yang paling stabil, menambahkan muatan (charge) pada setiap atom penyusun ligan, menambahkan atom hidrogen pada ligan, dan meminimalisirkan energi.

Proses docking pertama kali dilakukan dengan ligan standarnya dan harus mendapatkan nilai Root Mean Square Deviation (RMSD) kecil dari $2 \AA$. Hal ini berfungsi sebagai validasi metode docking yang akan digunakan. Jika syarat ini terpenuhi maka proses docking senyawa usulan dengan protein target dapat dilakukan. Hasil proses docking berupa energi dan binding site antara ligan dan residu asam amino. Interaksi yang muncul dapat berupa ikatan hidrogen dan ikatan phi, dengan masing-masing ikatan dibedakan dari warna ikatan yang terbentuk. Semakin kecil energi binding antara ligan dan protein yang dihasilkan, maka semakin stabil ikatan yang terjadi antara ligan dengan protein. (Syahri et al., 2017)

\section{HASIL DAN PEMBAHASAN}

Hasil maserasi disaring dan dipekatkan dengan rotary evaporator untuk mendapatkan 20,03 g ekstrak kental etil asetat $(0,67 \%)$ berwarna hijau pekat dari $3000 \mathrm{~g}$ simplisia kering (50\%) yang dikeringkan dari $6000 \mathrm{~g}$ daun segar katemas. Uji total fenolik dilakukan dengan metode Folin-Ciocalteu dengan asam galat sebagai larutan standar. Nilai absorbansi standar asam galat menghasilkan kurva kalibrasi larutan standar asam galat dengan persamaan linear yaitu $y=0,08 x+0,038$ dengan nilai $R^{2}=0,999$. Nilai absorbansi dari ekstrak etil asetat daun katemas diplotkan terhadap kurva standar asam galat dan dihitung kandungan senyawa fenoliknya. Kandungan total fenolik dalam ekstrak etil asetat daun katemas dinyatakan dalam GAE (Gallic Acid Equivalent) yaitu jumlah kesetaraan miligram asam galat dalam 1 gram sampel. Kandungan total fenolik dari ekstrak etil asetat daun katemas dapat dilihat pada Tabel 1.

Pengukuran total fenolik menggunakan metode Folin-Ciocalteu yang berdasarkan pada kekuatan mereduksi dari gugus hidroksi fenol. Menurut Ukieyanna (2012) senyawa fenolik bereaksi dengan reagen Folin-Ciocalteu 
dalam suasana basa sehingga terjadi proses disosiasi proton pada senyawa fenolik menjadi ion fenolat. Reaksi fenol dan Folin-Ciocalteu akan terlihat dari adanya warna kuning dan dengan menambahkan $\mathrm{Na}_{2} \mathrm{CO}_{3}$ akan memberikan warna biru. Semakin biru larutan menunjukkan semakin tinggi nilai absorbansi.

Tabel 1. Kandungan total fenolik dari ekstrak etil asetat daun katemas.

\begin{tabular}{lccccc}
\hline Sampel & Replikasi & Abs & $\begin{array}{c}\text { Rata-rata } \\
\text { Abs }\end{array}$ & $\begin{array}{c}\text { Fenolik awal } \\
\text { (mg/mL) }\end{array}$ & $\begin{array}{c}\text { Total Fenolik } \\
\text { (mg GAE/g ekstrak) }\end{array}$ \\
\hline Ekstrak etil asetat & 1 & 0,872 & & & \\
daun katemas & 2 & 0,874 & 0,873 & 0,10 & 4,24 \\
& 3 & 0,867 & & & \\
\hline
\end{tabular}

Uji total flavonoid dilakukan dengan reagen $\mathrm{AlCl}_{3}$ dengan kuarsetin sebagai standar. Dari nilai absorbansi kuarsetin sebagai larutan standar didapat kurva larutan standar dengan persamaan $y=0,008 x+0,065$, dan nilai $\mathrm{R}^{2}=0,999$. Nilai absorbansi dari ekstrak etil asetat daun katemas diplotkan terhadap kurva standar kuarsetin dan dihitung kandungan total flavonoidnya. Kandungan total flavonoid dari ekstrak etil asetat daun katemas dinyatakan dalam KE (Kuarsetin Equivalent) yaitu jumlah kesetaraan miligram kuarsetin dalam $1 \mathrm{~g}$ sampel. Kandungan total flavonoid dari ekstrak etil asetat daun katemas dapat dilihat pada Tabel 2.

Tabel 2. Kandungan total flavonoid dari ekstrak etil asetat daun katemas.

\begin{tabular}{lccccc}
\hline Sampel & Replikasi & Abs & $\begin{array}{c}\text { Rata-rata } \\
\text { Abs }\end{array}$ & $\begin{array}{c}\text { Flavonoid awal } \\
\text { (mg/mL) }\end{array}$ & $\begin{array}{c}\text { Kandungan Total } \\
\text { Flavonoid } \\
\text { (mg GAE/g ekstrak) }\end{array}$ \\
\hline $\begin{array}{l}\text { Ekstrak etil asetat } \\
\text { daun katemas }\end{array}$ & 1 & 0,723 & & & 3,22 \\
& 2 & 0,724 & 0,723 & 0,08 & \\
\hline
\end{tabular}

\section{Uji Aktivitas Antioksidan Ekstrak Etil Asetat Daun Katemas (E. heterophylla L.)}

Kandungan polifenol dan flavonoid dalam ekstrak dapat bertindak sebagai antioksidan yang akan bersifat sebagai donor elektron, bereaksi dengan radikal bebas untuk mengakhiri reaksi berantai yang terjadi. Berdasarkan hasil pengujian aktivitas antioksidan, diperoleh hasil bahwa ekstrak etil asetat daun katemas memiliki aktivitas antioksidan yang tergolong sangat kuat, seperti pada Tabel 3.

Tabel 3. Persen inhibisi ekstrak etil asetat daun E. heterophylla L. dan asam askorbat terhadap radikal bebas DPPH.

\begin{tabular}{lccc}
\hline Sampel & $\begin{array}{c}\text { Konsentrasi } \\
(\boldsymbol{\mu g} / \mathbf{m L})\end{array}$ & \% Inhibisi & IC $\mathbf{5 0}(\boldsymbol{\mu g} / \mathbf{m L})$ \\
& 500 & 96,52 & \\
Ekstrak etil asetat daun $E$. & 250 & 94,14 & 37,56 \\
Heteropylla L. & 125 & 90,29 & \\
& 62,5 & 69,41 & 7,92 \\
& 31,25 & 24,18 & \\
Asam askorbat & 15,625 & 94,42 & \\
& 100 & 72,68 & \\
\end{tabular}

\section{Uji Aktivitas Antidiabetes Ekstrak Etil Asetat Daun Katemas (E. heterophylla L.).}

Diet yang mengandung senyawa antioksidan mampu mengontrol kadar glukosa darah dan mencegah komplikasi DM (Pichaya et al., 2016). Uji aktivitas antidiabetes ekstrak etil asetat daun katemas (E. heterophylla L.) dilakukan secara in vitro dengan melihat besarnya penghambatan aktivitas enzim yang dilihat dari berkurangnya $p$-nitrofenil yang terbentuk bila dibandingkan dengan aktivitas enzim awal. Besarnya persen inhibisi yang dihasilkan dari setiap konsentrasi maka semakin banyak aktivitas enzim yang dihambat. Persen inhibisi ekstrak etil asetat daun katemas dapat dilihat pada Tabel 4. 
Nilai $\mathrm{IC}_{50}$ ekstrak etil asetat sebesar $138,6295 \mu \mathrm{g} / \mathrm{mL}$ nilai ini lebih rendah dibandingkan akarbose (standar) yang nilai $\mathrm{IC}_{50}$ sebesar $0,6799 \mu \mathrm{g} / \mathrm{mL}$. Hal ini disebabkan didalam akarbose terdapat satu senyawa aktif yang secara efektif dapat menghambat kerja enzim $\alpha$-glukosidase, sedangkan pada sampel eksktrak etil asetat daun katemas masih mengandung beberapa senyawa aktif yang memungkinkan terjadinya reaksi kompetisi antara senyawa yang ada didalam sampel ekstrak sehingga mempengaruhi daya hambat terhadap enzim $\alpha$-glukosidase semakin rendah (Hilma et al, 2016). Antioksidan dan komponen senyawa polifenol (fenolik dan flavonoid) mampu menangkap radikal bebas, membantu melindungi sel dari stres oksidatif, menurunkan ekspresi TNF- $\alpha$ dengan berbagai mekanisme sehingga dapat mencegah terjadinya perkembangan DM dan komplikasinya (Pichaya et al., 2016; Widowati, 2008).

Tabel 4. Persen inhibisi $\alpha$-glukosidase ekstrak etil asetat daun E. heterophylla L. dan akarbose.

\begin{tabular}{lccc}
\hline Sampel & Konsentrasi $(\boldsymbol{\mu g} / \mathbf{m L})$ & \% inhibisi & IC50 $(\boldsymbol{\mu g} / \mathbf{m L})$ \\
\hline & 1000,00 & 73,20 & \\
Ekstrak etil asetat daun & 500,00 & 65,96 & 138,63 \\
E. heterophylla L. & 250,00 & 56,90 & \\
& 125,00 & 48,75 & \\
& 62,50 & 40,50 & \\
& 31,25 & 32,13 & 0,68 \\
Akarbose & 10,00 & 89,93 & \\
& 5,00 & 80,29 & \\
& 2,50 & 69,05 & \\
\end{tabular}

\section{Docking Molekular}

Protein yang digunakan pada penelitian ini adalah alpha-glucosidase yang diunduh dari situs Protein Data Bank (PDB) melalui http://www.rcsb.org/ dengan kode ID PDB 3W37 (Gambar 1) pada manusia yang terkompleks dengan ligan akarbose dan diunduh dengan format berkas. pdb. Sebelum dilakukan docking molekular, validasi metode docking dilakukan dengan melihat nilai Root Mean Square Deviation (RMSD) yang dihasilkan oleh ligan standar dari struktur kristal protein. Besarnya penyimpangan jarak antara atom-atom yang bersesuaian pada ligan senyawa usulan dari pose awal dengan pose hasil re-docking ditunjukkan oleh nilai RMSD.

(a)

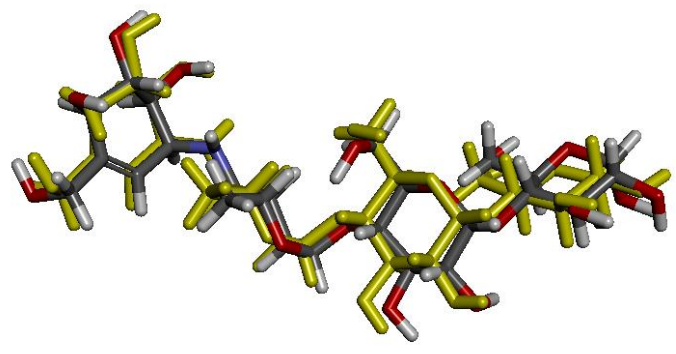

(b)

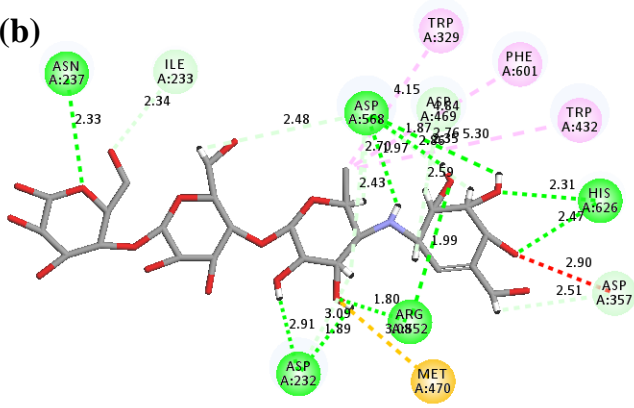

(c)

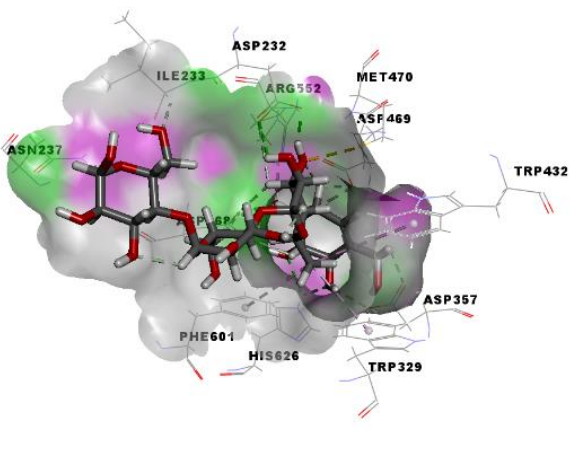

Gambar 1. (a) Pose ligan awal (warna sesuai atom) dan pose setelah re-docking (kuning); (b) dan (c) interaksi ligan standar (akarbose) dengan protein $3 \mathrm{~W} 37$. 
Semakin kecil nilai RMSD yang dihasilkan maka semakin baik kualitas docking yang dilakukan. Nilai RMSD terbaik dan memenuhi syarat yaitu $<2$ A. Nilai RMSD yang dihasilkan melalui re-docking akarbose terhadap protein $3 \mathrm{~W} 37$ adalah 0,8693 $\mathrm{A}$ (Tabel 4) maka dapat dikatakan metode docking molekul valid karena nilai RMSD < 2 A dan memiliki pose ligan re-docking yang sangat mirip dengan pose aslinya dapat dilihat pada Gambar 1. Maka proses docking senyawa (1) sampai (4) dapat dilakukan dengan protein 3W37. Ligan usulan yang digunakan untuk uji aktivitas antidiabetes secara in silico adalah senyawa-senyawa yang berhasil diisolasi dari famili Euphorbiaceae yang sefamili dengan daun katemas yang kemungkinan juga terdapat dalam sampel ekstrak etil asetat, dapat dilihat pada Tabel 4.

Tabel 4. Senyawa-senyawa yang berhasil diisolasi dari famili Euphorbiaceae.

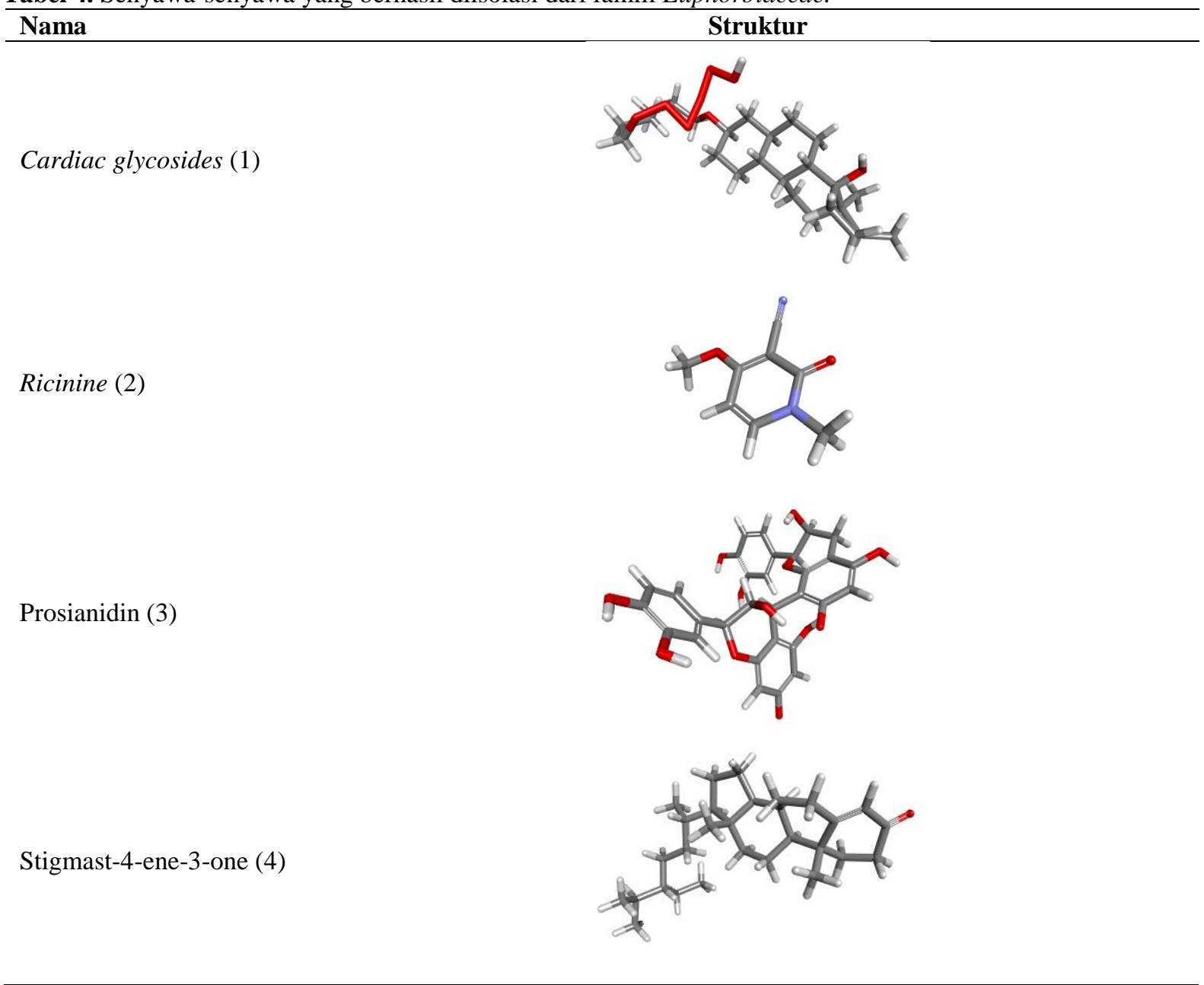

Docking molekular bertujuan untuk melihat interaksi antara ligan dengan protein yang menghasilkan ikatan hidrogen terhadap residu asam amino dan nilai -CDOCKER-ENERGY. Interaksi yang terbentuk antara ligan dengan protein dapat dilihat pada Tabel 5 menunjukkan bahwa semua senyawa usulan memiliki nilai CDOCKER-ENERGY lebih rendah dibandingkan akarbose $(25,53 \mathrm{kkal} / \mathrm{mol})$. Semakin mudah dan stabil ikatan ligan-protein yang terbentuk, maka semakin rendah energi ikat yang dihasilkan.

Tabel 5. Hasil simulasi docking senyawa usulan dan akarbose terhadap protein $\alpha$-glukosidase.

\begin{tabular}{lcc}
\hline Nama Molekul & -CDOCKER-ENERGY & Ikatan Hidrogen \\
\hline Akarbose & 25,5384 & ASP357, ASP232, SER497 \\
Cardiac glycosides (1) & 9,0844 & TYR437 \\
Ricinine (2) & $-6,00486$ & SER479 \\
Prosianidin & $-46,5493$ & LEU428, GLY429 \\
Stigmast-4-ene-3-one & $-31,5664$ & ASN425 \\
\hline
\end{tabular}

Hasil re-docking akarbose menghasilkan nilai RMSD 1,6118 Å, dengan nilai -CDOCKER-ENERGY 25,5384 kkal/mol dan membentuk ikatan hidrogen dengan residu asam amino ASP357, ASP232, dan SER497 
(Gambar 5). Secara umum semua senyawa usulan membentuk interaksi dengan residu asam amino lain yang dapat dilihat pada Tabel 5. Sehingga dapat disimpulkan bahwa semua senyawa usulan memiliki aktivitas antidiabetes, walaupun masih lemah jika dibandingkan dengan akarbose.

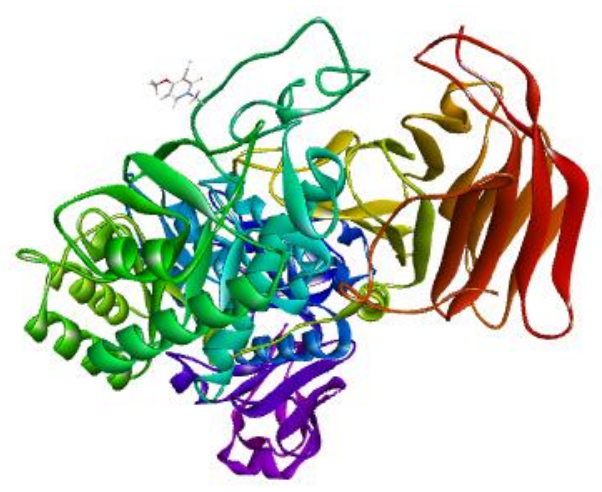

(a)
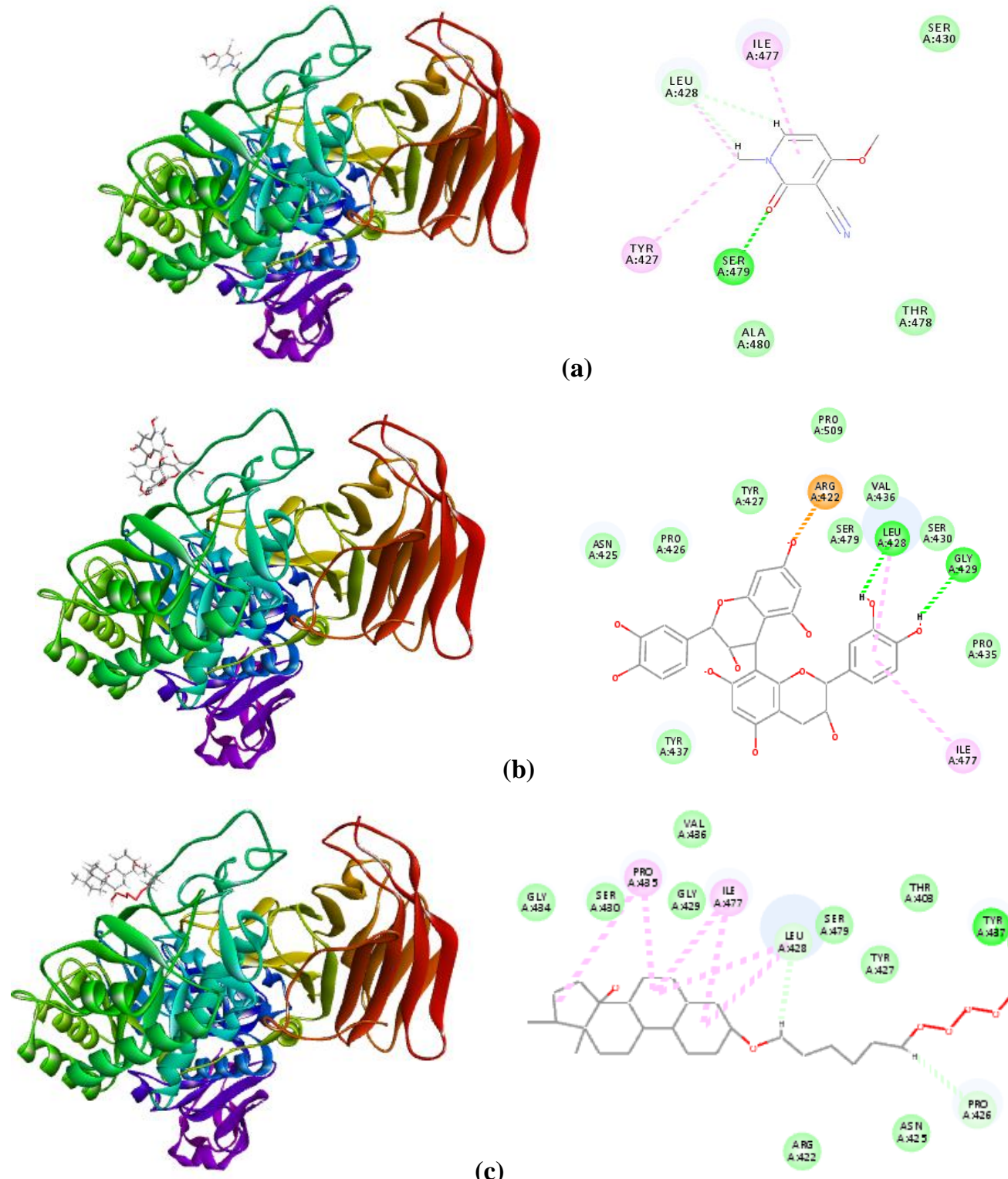

(b)
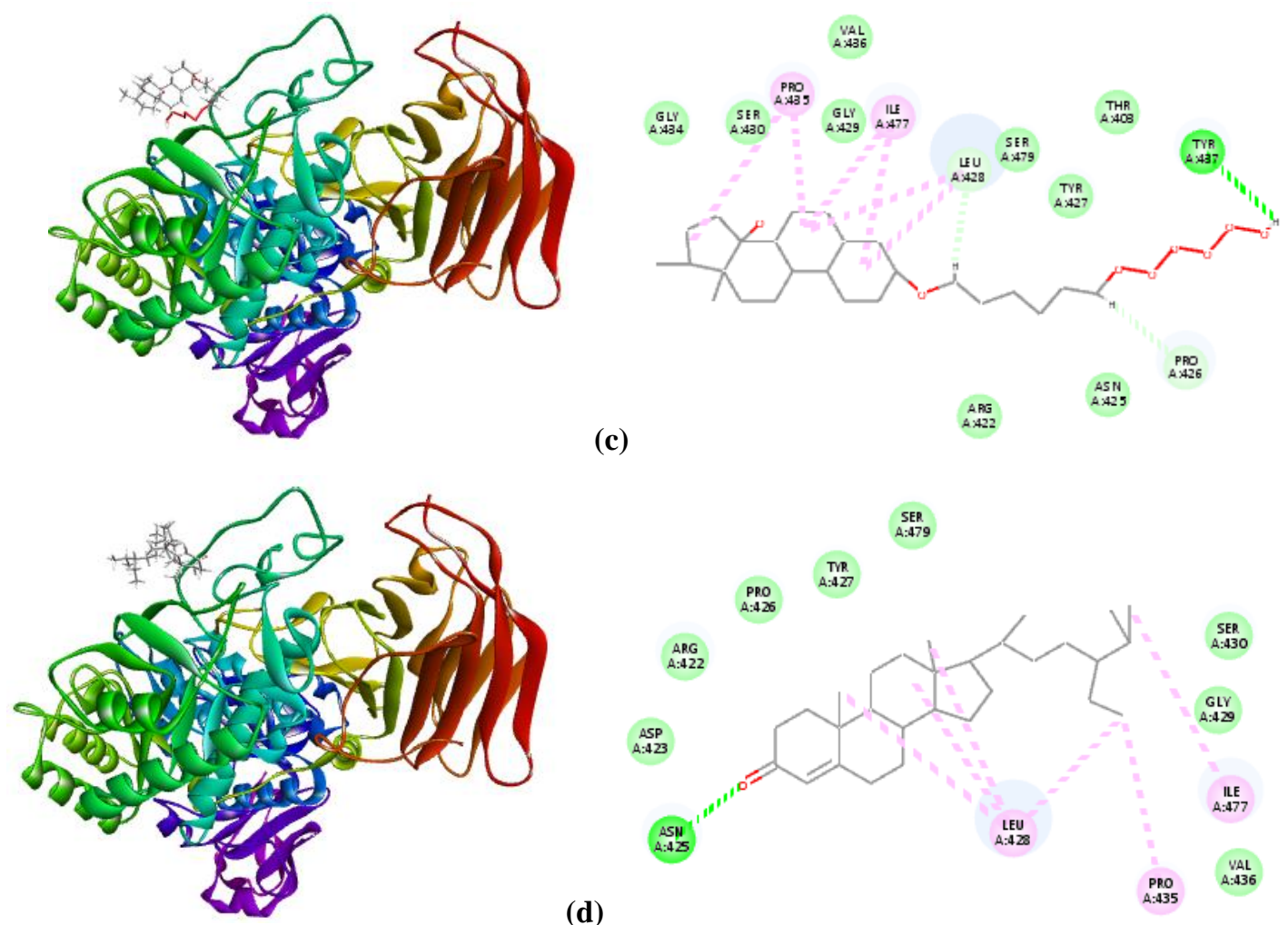

(c)

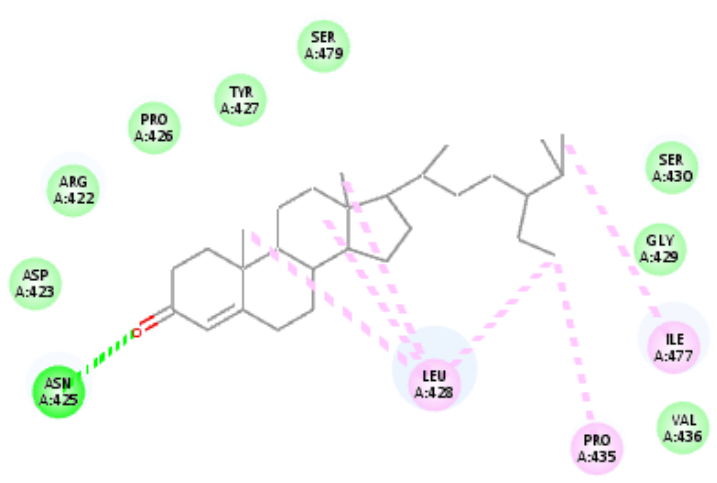

Gambar 2. (a) Interaksi Ligan Ricinine (1) dengan protein, (b) Interaksi ligan prosianidin (2) dengan protein (c) Interaksi ligan Cardiac glycosides (3) (d). Interaksi ligan Stigmast-4-ene-3-one (4) dengan protein. 


\section{KESIMPULAN}

Berdasarkan penelitian yang dilakukan dapat disimpulkan bahwa kandungan total fenolik dan flavonoid ekstrak yang tinggi mempengaruhi aktivitas antioksidan ekstrak yang tergolong sangat kuat serta aktivitas antidiabetes secara in vitro dan in silico. Hasil pengujian kuantitiatif total fenolik dan flavonoid ekstrak etil asetat daun E. heterophylla L. didapatkan nilai total fenolik ekstrak adalah 4,24 $\mathrm{mg}$ GAE/g berat kering dan nilai flavonoid total adalah: $3,22 \mathrm{mg} \mathrm{KE} / \mathrm{g}$ berat kering. Hasil uji aktivitas antioksidan ekstrak didapatkan nilai $\mathrm{IC}_{50}$ sebesar 37,56 $\mu \mathrm{g} / \mathrm{mL}$. Hasil uji aktivitas antidiabetes secara in vitro didapatkan nilai $I C_{50}$ sebesar $138,63 \mu \mathrm{g} / \mathrm{mL}$. Hasil docking molekular juga memperlihatkan bahwa senyawa-senyawa aktif yang terdapat didalam ekstrak mampu membentuk ikatan hidrogen antara ligan dengan protein, tetapi lebih sedikit dengan asam amino penting yang berperan sebagai antidiabetes dan memiliki nilai ikatan yang lebih kecil jika dibandingkan dengan akarbose.

\section{UCAPAN TERIMA KASIH}

Terima kasih disampaikan kepada Universitas Muhammadiyah Riau yang telah membiayai penelitian ini dengan Skim Penelitian Dosen Madya (PDM) TA 2019 dengan kontrak No. 017/KONTRAKPENELITIAN/K10/KM/2019.

\section{DAFTAR PUSTAKA}

Annapurna, A. and Hatware, K., 2014. Effect of Aqueous Extract of Euphorbia Heterophylla on Blood Glucose Levels of Alloxan Induced Diabetic Rats A. International Journal of Research in Pharmacy And Chemistry 4(3), 669-672.

Archana, N., Sah, Joshi, A., Juyal, V., and Kumar, T., 2011. Antidiabetic and Hypolipidemic Activity of Citrus medica Linn. Seed Extract in Streptozotocin Induced Diabetic Rats. Pharmacognosy Journal 3, 80 - 84. doi: 10.5530/PJ.2011.23.12.

Barla, A., Birman, H., kültür, Ş., and Öksüz, S., 2006. Secondary Metabolites from Euphorbia helioscopia and Their Vasodepressor Activity. Turkish Journal of Chemistry 30(3), 325-332.

Dalimartha and Adrian. 2012. Makanan Herbal untuk Penderita Diabetes Mellitus. Penebar Swadaya. Jakarta.

Falodun, A., Okunrobo, L.O., and Uzoamaka, N., 2006. Phytochemical Screening and Anti-inflammatory Evaluation of Methanolic and Aqueous Extracts of Euphorbia heterophylla Linn. (Euphorbiaceae). African Journal of Biotechnology 5(6), 529-531.

Febrinda, A. E., Astawan, M., Wresdiyati, T., and Yuliana, N. D., 2013. Kapasitas Antioksidan dan Inhibitor Alfa-Glukosidase Ekstrak Umbi Bawang Dayak. Jurnal Teknologi dan Industri Pangan 24(2), 161 - 167.

Hilma, R., Arafat, D.R., Fadhli, H., and Almurdani, M. 2017. Profil Fitokimia dan Aktivitas Antioksidan Ekstrak Daun Katemas (Euphorbia heterophylla L.). Proceedings of Seminar Nasional Pokjanas Tumbuhan Obat Indonesia Ke-52. Pekanbaru.

Hilma, R. Mukhlisa, S., and Fadhli, H., 2016. Aktivitas Antibakteri, Antijamur and Antidiabetes Ekstrak Kulit Buah Dimocarpus longan. Proceedings of SEMIRATA 2016 Bidang MIPA. Palembang.

Jalyeslml, F. and Abo, K. A., 2010. Phytochemical and Antimicrobial Analysis of the Crude Extract, Petroleum Ether and Chloroform Fractions of Euphorbia heterophylla Linn Whole Plant. University of Ibadan. Nigeria.

James, O. and Friday, E.T., 2010. Phytochemical Composition Bioactivity and Wound Healing Potential of Euphorbia heterophylla (Euphorbiaceae) Leaf Extract. International Journal on Pharmaceutical and Biomedical Research 1(1), 54-63.

Kumar, S., Malhotra, R., and Kumar, D., 2010. Antidiabetic and Free Radicals Scavenging Potential of Euphorbia hirta Flower Extract. Indian Journal of Pharmaceutical Science 72(4), 533-537.

Mansuri, M.I. and Patel, V.M., 2012. Antidiabetic Potential of Euphorbia neriifolia Linn. in Alloxan Induced Diabetic Rats. Journal of Pharmacy Research 5(5), 2571-2573.

Li, M., He, F., Zhou, Y., Wang, M., Tao, P., Tu, Q., Lv, G., and Chen, X., 2019. Three New Ent-Abietane Diterpenoids from the Roots of Euphorbia fischeriana and Their Cytotoxicity in Human Tumor Cell Lines. Archives of Pharmacal. Research 42(6), 512-518. doi: 10.1007/s12272-019-01151-y.

Olokoba, A.B., Obateru, O.A., and Olokaba, L.B., 2012. Type 2 Diabetes Melitus: A Review of Current Trends. Oman Medical Journal 27(4), 269-273.

Paul, T. and Banerjee, S., 2013. In Vitro Evaluation of $\alpha$-amylase Inhibitory Activity and Antioxidant Potential of Pteris vittata L. with Special Reference to Its HPTLC Profile. International Journal of Pharma and Bio Sciences; 4(2): 494-503. 
Pichaya, C., Srichaikul, B., and Talubmook, C., 2016. Antidiabetic and Antioxidant Activities of Seed Extract from Leucaena leucocephala (Lam.) de Wit. Agriculture and Natural Resources 50(5), 357 - 361. doi: 10.20959/wjpr20187-11812.

Rumape, O., 2013. Isolasi dan Identifikasi Senyawa Antifeedant dari Daun Jarak (Ricinus communis L.) terhadap Kumbang Epilachna varivestis Mulsant. Laporan Akhir Penelitian Hibah Doktor. Gorontalo. Universitas Negeri Gorontalo.

Rynjah, C.V., Devi, N.N., Khongthaw, N., Syiem, D., and Majaw, S., 2018. Evaluation of the Antidiabetic Property of Aqueous Leaves Extract of Zanthoxylum armatum DC. Using In Vivo and In Vitro Approaches. Journal of Traditional and Complementary Medicine 8(1), 134 - 140. doi: 10.1016/j.jtcme.2017.04.007.

Sui, X., Zhang, Y., and Zhou,W., 2016. In vitro and In Silico Studies of the Inhibition Activity of Anthocyanins Against Porcine ancreatic a-amylase. Journal of Functional Foods 21, 50-57, doi: 10.1016/j.jff.2015.11.042.

Syahri, J., Yuanita, E., Nurohmah, B. A., Armunanto, R., and Purwono, B., 2017. Chalcone Analogue as Potent Anti-Malarial Compounds Against Plasmodium Falciparum. Synthesis, Biological Evaluation, and Docking Simulation Study. Asian Pacific Journal of Tropical Biomedicine 7, 675 -679.

Ukieyanna, E., 2012. Aktivitas Antioksidan, Kadar Fenolik, dan Flavanoid Total Tumbuhan Suruhan (Peperomia pellucid L. Kunth). Fakultas Teknologi Pertanian, Institut Pertanian Bogor, Bogor.

Walker, R. and Whittlesea, C., 2012. Clinical pharmacy and therapeutics. Edinburgh: Elsevier.

Widowati, W., 2008. Potensi Antioksidan sebagai Antidiabetes, Maranatha Journal of Medicine and Health $7(2), 1-11$. 